\title{
EXPLORING FUTURE DEVELOPMENTS IN INTERNATIONAL OLIVE OIL TRADE AND MARKETING: A SPANISH PERSPECTIVE
}

\author{
Samir Mili and Manuel Rodríguez Zúñiga \\ Consejo Superior de Investigaciones Científicas \\ Instituto de Economía y Geografía \\ C/ Pinar, 25 \\ 28006 Madrid, Spain \\ Tel. + 34-914111098 Fax. + 34-915625567
}

\begin{abstract}
This article forecasts the main trends and likely developments affecting the Spanish olive oil export business over the next decade. A Delphi survey was conducted in 1999 with a highlyqualified panel of experts from the olive oil sector who, over two rounds of mailings, contributed their judgments about export prospects for the Spanish olive oil sector. Issues discussed include expected trends in world olive oil supply and demand, the likely implications of the major impending changes in the macroeconomic and regulatory setting, the characteristics of potential markets, the strengths and weaknesses of the Spanish olive oil export industry, and the key international marketing variables for the future. [EconLit citations: F140, Q130, Q170].
\end{abstract}

Keywords: world olive oil market, international marketing, export prospects, Delphi technique.

Published in Agribusiness: An International Journal, Vol.17, n 3, 2001, pp.397-415. 


\section{EXPLORING FUTURE DEVELOPMENTS IN INTERNATIONAL OLIVE OIL TRADE AND MARKETING: A SPANISH PERSPECTIVE}

\section{INTRODUCTION}

There is fairly widespread agreement in the specialized literature that the processes of globalization and commercial deregulation being induced by the policies of international organizations such as the World Trade Organization (WTO), the World Bank or the European Union (EU) have set up a new worldwide scenario of increasing challenges and opportunities for the agriculture and food sectors. From the supply point of view, these processes are creating openings for new products and for products from a variety of geographical areas in markets to which it had hitherto been difficult to gain access. This is provided, of course, that they meet certain requirements relating to quality (Hooker \& Caswell, 1996; Mahé, 1997) and to efficiency as part of integrated, stable agribusiness chains (Watts, 1995). It could be said that the environment for these products is becoming "truly transnational" (Barrett et al., 1999), in that tariff and nontariff barriers are gradually disappearing for the exchange of goods and services. Moreover, over the last two decades there have been dramatic changes in food demand in advanced societies. Although these are the result of a range of economic, demographic and socio-cultural factors, consumption patterns have been increasingly shaped by quality factors as opposed to the conventional economic variables (Meulenberg \& Steenkamp, 1991; Connor, 1994). A growing segment of consumers in these advanced societies is becoming more and more aware of the various aspects of product quality, such as the attributes of nutritional balance, health, image, presentation and general convenience (Fonte, 1998).

Hence, it is to this new, increasingly globalized economic environment which is very much conditioned by demand, that operators in the national agribusiness systems need to adapt their future production and 
commercial strategies. As one of these agribusiness systems, the olive oil sector has traditionally been characterized by low levels of development in markets outside the area of production. According to data from the International Olive Oil Council (IOOC), until recently the countries of the Mediterranean Basin were responsible for $95 \%$ of production and $90 \%$ of consumption worldwide ${ }^{1}$. However, during the nineties, a number of changes have taken place which are gradually altering these traditional patterns (Mili, 1999).

Firstly, in the main producer countries which in turn are the main consumers, olive oil consumption remained practically stable during the decade from $1987 / 88$ to $1997 / 98$, when worldwide consumption absorbed $98 \%$ of an average production per crop year of 1,921,100 tonnes and showed average annual growth of $2.1 \%$. More specifically, in the main producer countries of the EU, per capita consumption did not change significantly during this period - average annual per capita consumption was 10.5 kilos in Spain, 11 kilos in Italy and 19.5 kilos in Greece.

Meanwhile, in the markets defined as non-traditional, consumption increased almost exponentially. Trends in purchases in these markets over the last decade point to an appreciable, sustained growth in imports, although the situation varies from country to country. The United States became the largest purchaser, with imports rising from 64,500 tonnes in $1987 / 88$ to 147,500 tonnes in $1997 / 98$, which amounts to an average annual rate of growth over these two crop years of $8.6 \%$ (as opposed to an equivalent rate of $6.5 \%$ for all worldwide imports and $8 \%$ for the EU as a whole). The United States is now the world's fourth largest consumer of olive oil. In other relevant markets, although in terms of volume imports were lower than those of the United States, the average annual rates of growth for this period were even higher $-27.7 \%$ in Japan, $18.7 \%$ in Portugal, $17.7 \%$

\footnotetext{
${ }^{1}$ According to the United States Department of Agriculture (1999), of major vegetable and marine oils, olive oil accounts for only $2.8 \%$ of worldwide production and consumption and $3.3 \%$ of total trade (exports plus imports).
} 
in the United Kingdom, $14.2 \%$ in Germany, $13.2 \%$ in Canada, $10.2 \%$ in France and $9.6 \%$ en Australia2. The levels of consumption of many of these countries may not be very relevant in quantitative terms, but they are very relevant in qualitative terms because they focus on high-quality products with a high added value. An indicator for qualitative importance is the degree of penetration of the product - that is, the percentage of househols buying olive oil. In the United States, data from Market Segment Research Inc. show that the penetration index for this product almost tripled between 1986 and 1995, rising from 6.7\% in 1986 to $17.9 \%$ in 1995. In France the rate has doubled over the last 10 years, with the households consuming olive oil rising from 30\% in 1988 to 60\% in 1998, according to the French Committee for Olive Oil Expansion.

Secondly, with respect to supply, until the early nineties, worldwide production remained practically stable, mostly in a few countries within the Mediterranean Basin, showing the usual oscillations that are characteristic of this crop and that are caused by agricultural and climatic conditions. At the end of the eighties, distribution of worldwide production was as follows: Spain $30 \%$, Italy $25 \%$, Greece $17 \%$, Tunisia $9 \%$, Turkey $5 \%$, Portugal $2 \%$, and other Mediterranean countries 7\%. After this period of relative stability, in the nineties there was a change in the world geography of olive cultivation and an increase in supply which is considered by some sources to be above the potential demand $(I O O C, 1997)$. This was mainly the result of the increase in consumption in the nontraditional markets coinciding with the rise in international prices for the product caused by shortages in the Mediterranean during the first half of the decade and it led to increased public and private interest in olive cultivation in many countries, with a considerable extension of orchards and improved cultural techniques and practices. However, there is no full, homogeneous and reliable statistical information on either of these two aspects allowing for quantitative prediction of their effects on future worldwide supply. 
Thirdly, with respect to foreign trade, the trend in exports on a worldwide level shows that Spain has the highest figures in terms of volume and this, together with its low levels of imports, makes Spain the largest net exporter of olive oil. During the decade from 1987/88 to 1997/98, Spain's average share of world exports was $37.5 \%$, followed by Italy with $20.7 \%$, Greece with $16 \%$, Tunisia with $14.4 \%$ and Turkey with $3.5 \%$. A first reading of these data indicates a favorable situation for Spain but this needs to be qualified. On the one hand, Spanish olive oil exports are growing less rapidly than total world exports and those of the other main exporters (according to IOOC data for the $1987 / 88$ to $1997 / 98$ crop years, Spanish exports grew at an average annual rate of $6.9 \%$, whereas the rates for the whole world were $7.8 \%$, for Greece $12.8 \%$, for Italy $9.4 \%$ and for Tunisia 7.4\%). On the other hand, a high proportion of Spanish exports still are of bulk oil with a low added value, and the destinations of Spanish exports are relatively undiversified, with marked geographical specialization. After the three "classic" European Community destinations, namely Italy (57\% of total exports in 1997), France (12\%) and Portugal (10\%), the other countries with high growth and potential still absorb a small share of Spanish olive oil exports, although their import demand is still being increasingly met - in absolute terms but not in percentages - by Spanish exports.

Within this sectorial scenario, the export functions that are defined in the various countries involved will be of capital importance in reaching a balance between the product's usage and availability in the future. The objective of this study is therefore to establish a qualitative forecast for export prospects within the Spanish olive oil sector, based on the general hypothesis that these prospects depend on a series of macroeconomic, microeconomic and regulatory factors on which there is little empirical evidence or which are still the subject of public debate whose results are not clear, such as the forthcoming WTO trade negotiations and the future reform of the Common Agricultural Policy (CAP). It was also assumed that

\footnotetext{
2 Note that Portugal and France are net importer markets rather than non-traditional markets.
} 
although some of these factors act on a global level - such as the international regulatory framework to be established - others may vary from country to country and even within countries amongst different business segments. This means there is a wide spectrum of possible strategies for defining export propensity.

The study has four sections. After this introduction, section 2 explains the methodology applied, the findings are analyzed in section 3 and the main conclusions are drawn in section 4.

\section{METHODOLOGY}

Economic forecasting can be approached either quantitatively or qualitatively. The main difference between the two procedures is that while the former focuses on a quantified estimate of future values for the variables being studied, the purpose of the latter is to identify the trends and future directions for the variables (Fearne, 1989). The continuous changes in the socio-economic environment, their complexity and the speed with which they take place make it very difficult to accept the ceteris paribus assumptions that are implicit in most quantitative methods (Van Heerden, 1998). This is probably the reason for the increasing use over recent of qualitative forecasting techniques, of which the Delphi method is an advanced exponent. This procedure makes it possible, a priori, to consider all the relevant factors and the way they combine, thus generating a forecast from an essentially systemic perspective.

This study applies the Delphi method for reaching consensus over the most relevant factors defining future prospects for exports in the Spanish olive oil sector. Lato sensu, the Delphi method aims to systematically structure the information provided by a select group of individuals on a complex problem (Linstone \& Turoff, 
1975), with a view to establishing consensus (Woudenberg, 1991), although on some occasions it is also of interest to look at diverging and minority opinions (Buckley, 1995). This technique has been seen to be very useful in heuristic decision-making (Ziglio, 1996), and for clarifying complex, multi-dimensional problems (Russo \& McLaughlin, 1992)3. However, the Delphi method has not been applied to world trade and export strategies in the agricultural and food sector, even though many of the conditioning factors in the latter are constantly changing and difficult to quantify and therefore are appropriate for qualitative exploration.

The Delphi method was applied using a panel of experts from the olive oil sector, all having a high degree of responsibility and experience and coming from the business, academic and Administration areas in Spain. Special attention was paid to the design of the survey, which was carried out in 1999 in two rounds using two different questionnaires sharing nonetheless similar structure. This structure was based on a conceptual model that specifies the basic variables of the study and visualizes the ways in which these affect export prospects (Figure 1). It provides a simplified conceptualization of the premises outlined in the introduction, a sort of "preliminary or reference solution" to the problem posed in the Delphi. This model was constructed on the basis of the initial review and critical analysis of existing information on recent trends in the world olive oil market as a whole and on Spanish olive oil exports in particular. The central endogenous variable of the proposed model, the export prospects of Spanish olive oil sector, is considered to be conditioned by a set of factors (internal and external, macroeconomic and microeconomic), which can be classified into four clusters.

\footnotetext{
${ }^{3}$ The Delphi method has been applied with an acceptable degree of success in many areas, notably future technologies (Lefebvre et al., 1996; Coates, 1997), information science (Koskiala \& Huhtanen, 1989; Buckley, 1995), public economic and social policies (Preble, 1983; Alder \& Ziglio, 1996; Dinar et al., 1998) or marketing and international business (Larréché \& Montgomery, 1977; Czinkota \& Ronkainen, 1992 \& 1997), to give just a few representative examples. In the agribusiness sector, this technique has been used less frequently, although its flexibility has allowed it to be applied to such varying subjects as the setting of priorities for agricultural research (Calatrava Requena \& Navarro García, 1987), the future of the CAP (Fearne, 1989), the structural and organizational prospects for the food industry (Brock, 1981; Russo \& McLaughlin, 1992), the risk aversion of agricultural producers (Gunjal \& Legault, 1995) and future demand for nitrogen fertilizers (Taverdet-Popiolek, 1998).
} 
A first cluster of variables focuses on the future evolution of the world supply and demand of the product, i.e. the envisioned size of potential markets, as well as their geographic location. A second cluster refers to the future consequences of foreseen institutional changes and the evolving international macroeconomic context, particularly trends in globalization and technological advancement, as well as the EU process of economic and monetary integration. Thirdly, in an increasingly demand-driven food chain, consumer satisfaction emerges as one of the most relevant market traits for the future; hence the need to identify the profile and preferences of the potential consumer, making the distinction between traditional and nontraditional consumer markets. Lastly, the export capacity of Spanish agents is considered to be largely dependent on the structural (strengths and weaknesses with regard to international markets) and strategic (comercial and contractual behavior abroad) configuration of the export enterprises themselves, as well as on the evolution of the competitive business setting.

Based on this analytical framework, the first survey was addressed to eight experts selected from the three areas mentioned. It comprised a questionnaire with open-ended questions which were carefully designed on the basis of the information collected previously. The answers obtained were then used to draw up a second questionnaire with more structured questions. The items included were evaluated on 5-point scales for the degree of importance, impact, agreement or suitability, as appropriate. At the same time, the number of experts was increased, keeping the representation among the various professional backgrounds as balanced as possible. A total of 68 questionnaires were sent out (36 to businesses, 20 to academics and 12 to the Administration area). Of these, 42 were completed and returned (17, 15 and 10), giving an overall rate of response of $62 \%$ and partial rates of $47 \%, 75 \%$ and $83 \%$ in the respective professional areas. 
Most Delphi studies have been carried out with panels of 30 to 100 experts (Turoff \& Hiltz, 1996), although satisfactory results can be obtained with 8 to 10 (Johnson, 1976) and even 5 individuals (Rowe \& Wright, 1996). The well-documented flexibility in the application of the Delphi procedure (Rowe \& Wright, 1999) allows the possibility of controlled intervention both on the content of the questionnaire and on the number of experts by means of new incorporations over successive rounds (Landeta, 1999). In the present study, on the basis of the high degree of consensus reached in the first round, it was decided to maintain the basic content of the questionnaire but to increase the number of experts in the second round, in order to enhance the robustness of such consensus. Obviously, the panel did not include all individuals who have a high expertise in the olive oil sector and the results should therefore be considered as explorative rather than conclusive.

The quality of the answers received was evaluated according to a set of criteria that are widely accepted by the specialized literature, such as the internal coherence of answers, an admissible degree of dispersion expressed in terms of the coefficient of variation (cv) below 50\% (Dinar et al., 1998), and a minimum threshold of 30 valid answers (Czinkota \& Ronkainen, 1997). Based on these parameters, the results can be considered satisfactory because, when examined individually, the answers show a fair degree of internal consistency, the $\mathrm{cv}$ is below $50 \%$ and the number of answers was 30 or more for practically all the variables 4 .

\footnotetext{
${ }^{4}$ Apart from the achievement of a robust consensus, no substantial differences were observed in the responses from the first and second round, which ensures the stability criterion needed to end the procedure (Woudenberg, 1991; Mitchell \& McGoldrik, 1994). However, it is worth noting that although a third iteration would have been necessary for variables that did not reach the degree of consensus and stability thresholds (see Table 1), it was not done because this was the case for only two variables which were not central to the study.
} 
The participants were also asked to make a self-assessment of their expertise by inserting for each question a score from 0 to 5 in a "Self-Assessment" space. The degree of knowledge of the experts on the matters being studied was seen overall as intermediate to extensive. The average self-assessment for the panel for the whole of the survey was 3.35 ( $c v=28.36)$, with the business representatives giving the best self-assessment on average $(3.67, \mathrm{cv}=19.89)$, followed by the groups of experts from the Administration $(3.38, c v=27.51)$ and the academics $(2.99, c v=34.45)$. The self-assessment values were used to weight the responses, based on the assumption that, a priori, the experts with a high self-assessment gave more precise and more representative answers than those whose self-assessment was low (Michell \& McGoldrick, 1994). This weighting procedure made it possible to calculate the weighted averages, which in many cases were seen to be significantly different from the unweighted averages.

\section{RESULTS AND DISCUSSION}

Below is a summary of the main consensus views arising from the responses obtained in the second round of the Delphi, showing the central tendency by means of the average score weighted by the selfassessment index $(\bar{Z})$, and the dispersion of the answers expressed by the coefficient of variation.

\subsection{Expected trends in worldwide supply and demand for olive oil}




\subsubsection{Potential supply}

The magnitudes of increase of potential supply by countries point to a probable speeding-up of the rate of growth for worldwide production. In the coming decade, the rates of growth in most of the countries in which significant increases in production are expected are very likely to be higher than the $2 \%$ increase seen during the period from $1987 / 88$ to $1997 / 98$ (Table 1). The highest rates will probably be seen in Argentina and Australia. Within the group of Mediterranean producers, the expected growth in production in any one country does not necessarilly tally with its specific weight in worldwide production, except for Spain which is the country in this group with the highest expected growth rates. Italy and Greece which, respectively, are the second and third largest producers in the world, are likely to show lower rates of growth. Hence, except for Spain and, to a lesser extent, Portugal, the growth in production in the EU is expected to be moderate in comparison with the increases expected in the non-EU producer countries in the southern Mediterranean Basin, especially Tunisia, Morocco, Turkey and Syria5.

Concerning the degree of impact on Spanish exports of the increases in production expected in each country, the results suggest that the greatest impacts will come from future increases in Spain, Tunisia and Turkey. The product of the variables of magnitude of increase and degree of impact makes it possible to draw up a synthetic index for what could be called the potential impact on exports of increased supply. According to this indicator, which ranges between 1 and 100, the countries with the greatest potential impact are Spain, Tunisia, Morocco, Turkey and Syria, while Italy, Greece and Portugal show the lowest

5 These trends are in line with those indicated by the IOOC projections for production and consumption of olive oil by 2005 (IOOC, 1997). 
rates. Of note here is the low impact assigned to future production increases in Italy, even though Italy is Spain's main competitor in foreign markets.

With respect to the determining factors for future growth in worldwide supply, the consensus obtained referred to seven factors, the relative importance of which was evaluated on a scale of 1 (not important) to 5 (very important). Thus, growth will be determined by new orchards in traditional producer countries $(\bar{Z}=3.91, \mathrm{cv}=28.39)$, rising productivity as a result of improved cultural practices $(\bar{Z}=3.83, \mathrm{cv}=24.54)$, new orchards in countries which are traditionally non-producers $(\bar{Z}=3.64, \mathrm{cv}=31.04)$, prices stimulating expansion of olive farming $(\bar{Z}=3.35, \mathrm{cv}=35.82)$, application in the future of technological innovations (genetic, mechanical, etc.) which so far has been limited in olive cultivation ( $\bar{Z}=3.31, \mathrm{cv}=25.68)$, CAP aid to production $(\bar{Z}=3.13, \mathrm{cv}=40.26)$ and advances in extraction techniques $(\bar{Z}=2.86, \mathrm{cv}=33.22)$.

Special attention should be paid to the new plantations in countries traditionally non-producers such as Argentina and Australia. In Argentina, the nineties have seen the start of a period of very significant development for olive cultivation and olive oil production after the abandonment and falling production of the seventies and eighties. According to Marginet Campos (1999), this changing trend has come about as a result of three factors - the promotion of olive oil as being beneficial for health, higher international prices for olive oil and the tax incentives granted by the Administration to encourage investments in the agricultural sector. Similar reasons are behind the upsurge in cultivation in Australia (Tous Martí, 1995). Olive cultivation in both countries is therefore expected to continue increasing, bringing with it modernization and considerable improvement of industrial extraction capacity ${ }^{6}$.

\footnotetext{
6 It must be remembered, however, that in Argentina, and even more so in Australia, the production thresholds are fairly low in comparison with other producer countries. In addition, while Argentina already exports and will increase its export capacity over coming years, Australian production aims to supply a growing domestic market and to replace imports.
} 


\subsubsection{Potential demand}

Table 2 shows the geographical location, the magnitude of increase, the degree of impact and the rate for potential impact for the expected increases in consumption. There are many geographical areas in all parts of the world in which increases in demand are expected, and this suggests that the trend towards international expansion of the product will intensify. The highest increases are expected in Japan, the United States, Australia, Canada, France and the non-producer European Union countries while no perceptible increase is detected for the largest EU producers (Spain, Italy and Greece), which over the last decade together accounted for $66 \%$ of world consumption. The results show also that the greatest impact on Spanish trade flows of the expected increases in consumption will come from Japan, Australia, the United States, France, Canada and the non-producer EU countries, respectively.

The degree of impact in the case of Japan is especially high (66), probably due to two considerations on the part of the experts - on the one hand, the very positive evolution over recent years in olive oil consumption in this country of 125 million inhabitants where consumers have a high income and are increasingly aware of the health and cultural aspects of food and, on the other, Japan's increasing participation in food trade with the rest of the countries in the Pacific Basin which has in some way converted it into a platform for product re-dispatching and therefore an important point of entry in these markets. This is also been happening in the case of the United States with respect to Canada, in that a sizable proportion of Canadian olive oil imports in fact are re-forwardings from the United States. 
With respect to the determining factors behind the above increases, there is broad agreement on these, with the emphasis on those that are directly or indirectly related to promotion and product image. Future increases in consumption are especially attributed to improved coordination of promotion activities ( $\bar{Z}=4.56, \mathrm{cv}=17.70)$, greater involvement of the sector as a whole in promotion activities $(\bar{Z}=4.41$, $\mathrm{CV}=16.10)$, intense, on-going promotion in emerging countries $(\bar{Z}=4.38, \mathrm{cv}=17.12)$, increasing prestige of the Mediterranean diet $(\bar{Z}=4.28, \mathrm{cv}=15.65)$, and the increasing tendency amongst consumers to include new products in their diets $(\bar{Z}=3.91, \mathrm{cv}=18.93)$. The strictly economic variables have some relevance but seem to exert relatively less influence as shown in the rest of the factors on which agreement was reached - stable prices that prevent large price fluctuations ( $\bar{Z}=3.91, \mathrm{cv}=22.76$ ), and increased purchasing power in the countries with the greatest potential for consumption $(\bar{Z}=3.71, \mathrm{cv}=24.80)$ and in non-EU Mediterranean producer countries $(\bar{Z}=3.21, \mathrm{cv}=30.22)$.

On the matter of the balance between supply and demand on a worldwide level, the experts agree that worldwide supply of olive oil will increase significantly in the future $(\bar{Z}=4.17, \mathrm{cv}=17.99)$ and that, unless there are long periods of drought in more than one of the main producer countries, supply will exceed worldwide demand in the long term $(\bar{Z}=3.65, \mathrm{cv}=29.04)$. In order to achieve parallel increases in demand, it will be necessary to be more efficient in promotion $(\bar{Z}=4.68, \mathrm{cv}=12.18)$ and in product distribution $(\bar{Z}=4.28, \mathrm{cv}=21.26)$, much more than in production $(\bar{Z}=2.88, \mathrm{cv}=42.01)$. In particular, Spain will be one of the countries with the largest surpluses unless it brings down its future increases in production $(\bar{z}=3.90$, $\mathrm{CV}=28.46)$. In addition, the Spanish supply in foreign markets will have to compete increasingly with Italy in the top-segment $(\bar{Z}=4.38, \mathrm{cv}=16.89)$, and with the non-EU producer countries in the lower-quality segment $(\bar{Z}=3.88, \mathrm{cv}=28.35)$. 


\subsection{Implications of changes in the macroeconomic and regulatory environment}

\subsubsection{Implications of changes in the international economic environment}

The changes that are taking place in the international economic environment (especially globalization, deregulation, technological development, the introduction of the Euro) can be expected to affect olive oil trade in a number of areas and ways. The results obtained in this respect suggested that the effects could be grouped into three areas, namely the world, the European Union and Spain. The consensus views reached were evaluated according to the degree of agreement attained.

On a worldwide level, these processes, especially interventionist deregulation, will on the whole be positive as they will help to intensify trade flows $(\bar{Z}=3.79, \mathrm{cv}=27.18)$. In addition, international competition will increase in markets that will become increasingly segmented according to the different qualities and presentations $(\bar{Z}=4.36, \mathrm{cv}=15.14)$. This points to the need for importer countries to adopt the quality standards of the EU and the IOOC to prevent fraud in oil quality $(\bar{Z}=4.65, \mathrm{cv}=12.69)$.

In the EU, the introduction of the Euro is expected to have positive effects on intra-Community trade because trade operations will speed up $(\bar{Z}=4.22, \mathrm{cv}=20.14)$ and intra-Community price differences will tend to become narrower ( $\bar{Z}=3.72, \mathrm{cV}=27.42)$. At the same time, consumption of virgin olive oils in the EU will increase $(\bar{Z}=4.19, \mathrm{cv}=14.32)$, and the process of gradual substitution of bulk export sales by packed oils will speed up $(\bar{Z}=3.79, \mathrm{cv}=22.69)$. 
With regard to Spain, this being the country with the largest exportable surplus in the world, it will be the greatest beneficiary of every aspect that facilitates international trade $(\bar{z}=3.94, \mathrm{cv}=22.59)$, although it will be the most affected by the increased access by competing countries to international markets $(\bar{Z}=3.55$, $\mathrm{cv}=26.76)$. In this context, the experts have two main concerns for the future. On the one hand, they consider a balance would need to be sought in the support received by olive cultivation and that for other types of products in order to prevent the continuing expansion of the olive growing surface area $(\bar{z}=3.42$, $\mathrm{cv}=32.75)$. On the other hand, they consider the introduction of the Euro and, in general, the consolidation of the European Single Market could encourage the presence of Italian operators in Spain $(\bar{Z}=3.50$, $\mathrm{CV}=25.14)$.

\subsubsection{Effects of the institutional changes in the EU}

There are four main factors of institutional change that will be affecting the olive oil sector in the EU over the coming decade - the reform of the Common Market Organization (CMO) for olive oil, the forthcoming round of negotiations of the WTO, the enlargement of the EU to the Central and Eastern Europe Countries (CEEC) and the dialogue with the Southern Mediterranean countries on the creation of a free trade area by the year 2010. The consensus views reached on these matters were evaluated according to the degree of agreement attained.

Concerning the Common Market Organization for olive oil, it should be recalled first that it was reformed in 1998 establishing, in comparison with the previous regulation, an increase of $32 \%$ in the maximum amount entitled to subsidies, a system of national quotas for the distribution of aid, a system of aid for private storage instead of State intervention, and the granting for the first time of subsidies for table olives. 
However, these reforms were only temporary because the provisions only apply to the three crop years over the period 1998/99 to 200/01, and definitive reform is planned as from the 2001/02 crop year. With regard to future regulations, the experts place special emphasis on aspects related to fair aid distribution, market transparency and external competitiveness not related to public aid. They argue that the forthcoming reform is likely to remove the competitive disadvantages that exist at present amongst the EU producer countries $(\bar{z}=4.26, \mathrm{cv}=26.76)$, and that the greater the transparency of the market and the less the sector depends on aid, the greater its export capacity will be $(\bar{Z}=3.76, \mathrm{cv}=29.25)$. They consider that the EU will probably reduce its intervention in this sector, establishing an export policy based on image, quality and "reasonable" prices ( $\bar{Z}=4.07, \mathrm{cv}=27.03)$, and that tariff barriers against imports of olive oil from third countries may favor producers but make it much more difficult for exporting companies to compete, as the presence of non-EU olive oil increases in foreign markets $(\bar{Z}=3.40, \mathrm{cv}=36.18)$.

The opinions recorded on the probable effects on the olive oil sector of the new WTO round of multilateral negotiations are in line with what can be expected for the whole agricultural and food sector, taking into account the global framework and the schedule for the negotiations ${ }^{7}$. There is a clear perception that export refunds will disappear and production aid will decrease $(\bar{Z}=3.97, \mathrm{cv}=24.68)$ and that, in general, the continued process of commercial deregulation and aid reduction will favor the more competitive producer countries, among them Spain $(\bar{Z}=3.65, \mathrm{cv}=31.78)$. In addition, the experts maintain that during the negotiations pressure will be applied to replace the current production aid with aid per tree or, alternatively, per surface area $(\bar{Z}=3.58, c v=37.15)$.

\footnotetext{
${ }^{7}$ Josling and Tangermann (1999) have carried out an interesting analysis of the agricultural matters to be dealt with in the next WTO round and of the possible positions of the various commercial blocks. The negotiations concerning agriculture are not expected to be easy, especially because of the persistent agricultural protectionism existing in many countries. This causes frequent trade frictions as shown in the fact that the number of trade litigations presented to the WTO's Dispute Settlement Body
} 
The enlargement of the EU to include the CEEC will increase potential for exports although these markets will take some time to reach significant volume $(\bar{Z}=4.06, \mathrm{cv}=17.49)$ and, as was the case in other nontraditional markets, consumption in these countries will begin on a small scale amongst consumers with a high income level $(\bar{Z}=4.44, \mathrm{cv}=11.26)$. However, the enlargement will mean the EU will allocate fewer resources to the development of olive oil markets $(\bar{Z}=4.42, \mathrm{cv}=12.90)$, with the resulting induced effect on prices and returns for the EU olive oil sector.

Finally, with respect to the EuroMediterranean dialogue ${ }^{8}$, the association agreement will encourage EU operators to set up operations in non-EU Mediterranean producer countries $(\bar{Z}=4.23, \mathrm{cv}=15.84)$. This economic rapprochement will also give rise to the establishment of new tariff quotas with these countries, thus increasing the possibility of supplying oil at prices below the European prices $(\bar{Z}=3.89, \mathrm{cv}=16.97)$. In addition, the Southern Mediterranean countries are unlikely to increase their domestic demand for olive oil so any additional commercial advantage will increase their competition in international markets, at least for bulk products $(\bar{z}=3.96, \mathrm{cv}=15.66)$. Meanwhile, in view of the competition in prices from these countries, the Spanish export industry will have to compete by consolidating qualities and brands in foreign markets $(\bar{Z}=4.50, \mathrm{cv}=16.89)$.

\subsection{Prospects for external expansion: characteristics of potential markets and business}

\section{strategies}

is proportionately greater than the weight of agriculture in world trade (Organisation for Economic Cooperation and Development, 1998).

${ }^{8}$ For a prospective analysis of the likely scenarios for the EuroMediterranean partnership policy applied to the olive oil sector, see Bonazzi and Gomez Paloma (1997). 
After establishing predictions for probable future trends in both supply and demand for olive oil on a worldwide scale and for the macroeconomic and regulatory factors affecting the olive oil sector, the third section of the survey covered expectations for foreign expansion of the product from a microeconomic and commercial point of view. To convert the potential for consumption in new markets into real demand inevitably requires that operators apply active export policies, taking into account the characteristics of the markets and of potential consumers. The first step was to determine the main characteristics of the potential external markets, focusing on two main aspects - consumer profiles and the adaptation of products to these markets. Subsequently, export perspectives for the Spanish companies were explored, analyzing certain aspects of business structure, methods for penetrating new markets, the international marketing mix and institutional support for exports.

\subsubsection{Characteristics of potential markets}

The experts were requested to define the main features of consumption and potential uses of olive oil in the markets where demand is expected to increase over the coming decade, making distinctions in their assessments between producer countries (PCs) and non-producer countries (NPCs) (Table 3). The experts pointed to the increased importance in the future of the quality factor as against prices and agreed that there is a wide margin for growth in consumption if there is a change in the price ratio favorable for olive oil. At the same time, they expect growth and greater diversification over the coming years in both food and 
non-food uses for olive oil. Moreover, they stress the existence of a large margin for growth in olive oil consumption amongst young, urban populations, and in consumption outside the home.

With respect to the attributes of olive oil which are considered most appropriate for efficient marketing in potential markets, both in PCs and in NPCs, the experts identified four relevant attributes which have been classified according to their relative importance (Table 4). These attributes are fruitiness, low acidity, "personality" and mildness.

In view of the strong international competition both between olive oil and other fats and oils and actually within the olive oil market, the criteria for differentiating Spanish olive oils in foreign markets were explored (Table 5). The factors suggested can be said to be in line with modern consumer demand in the developed countries. Hence, in comparison with substitution products, Spanish olive oils would need to be differentiated in foreign markets based mainly on the attributes of a healthy, natural and good-tasting product, with special attention being paid to presentation and the environmental benefits. For oils from competing countries, the main variables for differentiation are likely to be the brand and the country image, without forgetting the use of denominations of origin and varietal differentiation according to the growing location.

\subsubsection{The Spanish olive oil business sector and the export challenge}

According to the experts, the main strengths of the Spanish olive oil export business is the high quality of its products. In addition, it has sufficient industrial capacity to be able to meet the needs of import demand, a long exporting tradition and a high degree of business concentration (Table 6). The main weaknesses, however, lie 
in the area of marketing, with improvements being required in the image of Spain in many importer markets, in the creation of exporter's own distribution channels, in both general and brand promotion, in the reduction of the share of bulk products in exports, in international price-competitiveness and in the elimination of the regulations which distort competition.

With respect to the methods of penetration in new markets, the most suitable formulae are agreements with import and marketing organizations or companies at the destination (joint ventures, strategic alliances, etc.) $(\bar{Z}=4.22, \mathrm{cv}=17.54)$. Other less favored formulae are the purchase of a business with a market share at the destination $(\bar{Z}=3.79, \mathrm{cv}=29.81)$, the creation of commercial subsidiaries at the destination $(\bar{Z}=3.79$, $\mathrm{cv}=27.70)$, the possession of a trade representative at the destination ( $\bar{Z}=3.63, \mathrm{cv}=25.62)$, and marketing through export consortia ( $\bar{Z}=3.55, \mathrm{cv}=29.86)$. Much less relevance is given to other options which might usually be considered valid such as the installation of packaging and marketing centers in non-EU producer $\operatorname{countries}^{9}(\bar{Z}=2.98, \mathrm{cv}=37.58)$, direct sales (through international catalogues, the Internet, etc.) $(\bar{Z}=2.94$, $\mathrm{cv}=40.48)$, the creation of facilities for packaging and marketing at the destination ${ }^{10}(\bar{Z}=2.79, \mathrm{cv}=40.86)$, and sales through trading companies $(\bar{Z}=2.76, \mathrm{cv}=35.87)$.

Having studied the international environment, noted market trends, selected target markets and decided on the method for entering them, export companies will need to draw up and set in operation an international marketing program. Table 7 shows the various dimensions of the four basic variables of the marketing-mix

\footnotetext{
9 This formula was applied recently by a number of large companies in the Spanish olive oil industry which thus opted for new methods of internationalization based on externationalization of production and industrial implantation in third producer countries, going beyond the traditional methods based on the shipping of products to foreign countries. The most representative example is probably that of the company Aceites del Sur, which is currently carrying out refining and packaging in Argentina and has plans to set up production complexes (milling, refining and packaging plants) in Tunisia, Turkey and Syria.

10 This formula is also being applied by some Spanish exporters such as the Borges group which has set up trade subsidiaries in California and on the east coast of the United States.
} 
ranked according to the degree of their relative importance, which the experts considered the most relevant for international trade over the coming decade. Taken together, decisions on product characteristics, pricing strategies, links with distribution channels and communication policies will be increasingly important factors for success in foreign markets. It can be observed that the importance assigned to pricing aspects was lower than that assigned to those related to the other three variables. This means that, in line with the other evaluations carried out by the experts on this subject, the price will rarely be the main variable for competing in foreign markets.

Finally, business strategies for foreign trade are usually coordinated with public actions aiming to promote exports. It must be remembered that public institutions involved in the promotion of exports play a decisive role in the generic promotion of olive oil with the resulting increase in global demand. The experts considered that, in order for institutional support to contribute efficiently to increasing the presence of olive oil in foreign markets, it would need to focus especially on matters relating to coordination and cooperation in promotional activities, personalization of marketing and reinforcement of the country's image (i.e. the made in Spain label). Thus, they insisted that there is need for greater coordination amongst the various administrative bodies involved in exports $(\bar{Z}=4.47, \mathrm{cv}=14.32)$, measures targeting the end consumer more directly $(\bar{Z}=4.45, \mathrm{cv}=17.53)$, greater involvement of the whole sector in the matter of exports $(\bar{Z}=4.39$, $\mathrm{CV}=18.45)$, and promotion of the country's image $(\bar{Z}=4.19, \mathrm{cv}=23.87)$; meanwhile, the promotional activities which have been carried out so far must be maintained $(\bar{Z}=4.10, \mathrm{cv}=20.49)$.

\section{SUMMARY AND CONCLUSIONS}


The increasingly globalized and demand-driven economic scenario that is beginning to take shape for the coming millennium will offer new challenges and opportunities for the agricultural and food sectors, one of which obviously is the olive oil sector. The success to be obtained in achieving sustained, stable competitive advantages in foreign markets will depend on the production, organization and commercial strategies adopted. In this sense, this study presents the structured opinions of a representative group of highly-qualified experts in the olive oil sector from several different responsability areas. These appear to outline a future scenario with increases in world supply above those in demand, lower requirements for regulation and interventionism, greater attention to the preferences of potential consumers, and a greater focus on quality and marketing-mix functions as key factors of competitiveness. This general framework could in turn be broken down as follows.

Firstly, a gradual increase in the world supply of olive oil is expected, mainly as a consequence of the entry into production of new orchards and improved cultural practices. This will lead to greater prominence for nonEU producer countries. Spain, meanwhile, will continue to be the world's largest producer and will even play an increasingly important role. Worldwide demand will increase, especially because of new consumers in developed countries where olive oil consumption is not traditional. However, consumption in traditional countries will remain at its current levels or, at the most, will record low rates of growth. Forecasts concerning the balance between usage and availability suggest that, although both variables will increase, the rates of increase in worldwide supply will be greater than those for demand, except during crop years in which there are adverse agricultural and climatic factors. This consideration, which is valid in general terms for all exporter countries, is especially valid for Spain which is expected to show significant increases in supply although domestic consumption is not likely to rise significantly. The result of these trends taken together will be an appreciable advance in the process of globalization for the sector, leading to increased competition amongst countries and 
amongst Spanish national economic agents (mostly in the top-quality segment) and, as a result, increasing prominence for national and entrepreneurial export promotion activities.

Secondly, the changes in the international economic environment are expected to speed up internationalization of the sector by enhancing market transparency. With respect to the regulatory framework, in connection with both the forthcoming WTO negotiations and the future reforms of the CMO, there is general agreement on the advisability of greater market transparency, increased commercial deregulation and the reduction of subsidies, all of which will favor the most competitive producer countries, one of which is Spain. The extension of the EU to include the CEEC is seen from two points of view - on the one hand, as an opportunity to expand markets in the long term and, on the other, as a reason for reduction of the funds allocated by the CAP to sectors such as the olive oil sector. The latter confirms the perception that there will be fewer subsidies for the sector in the future. The EuroMediterranean dialogue is also seen as leading to deregulation and greater transparency. It is likely to result in greater economic rapprochement in the area, thus increasing the scope for action of EU operators in Mediterranean producer countries. For Spain, a more competitive scenario would be preferable but would bring two main concerns. Firstly, the current expansion in olive farming would need to be reduced by searching for a balance between aid for olive cultivation and other actions targeting quality improvement. Secondly, more dynamic trade flows might increase the presence of Italian firms in Spanish business.

Thirdly, in producer countries, the greater increase in consumption will be the result of demand from a segment of the population that is concerned about the quality of its diet rather than the relative price level. Similar trends, although even more marked, are perceived for non-producer countries, although in this case there is also a large margin for growth in consumption among the young, urban populations. Specifically in 
the area of non-EU producer countries, significant increases in domestic consumption are not expected, so the increased production in these countries will increase worldwide supply and may bring prices down, especially in the segment for bulk products. Potential markets will demand mainly fruity, mild oils with low acidity and "personality". Differentiation of Spanish oils in foreign markets with respect to substitute products would need to be based mainly on the attributes of a healthy, good-tasting product and would need to place special attention on presentation and environmental factors. For oils from competitor countries, the main factors for differentiation are expected to be the brand and country image.

Fourthly, Spanish olive oil exporters in general have sufficient industrial capacity to meet the requirements of importers both in time and form, their main weaknesses lying in the area of marketing. In order to enter new markets, the most suitable methods will probably be agreements with import and distributive organizations or companies at the destination. The international marketing-mix will have priority in the future strategies of export companies. The decisions taken on product characteristics, pricing, relations with distribution channels and communications policies will become increasingly important for success in more and more globalized and deregulated foreign markets. Along these lines, institutional support for exports, with better coordination, implementing measures that target the end user directly and involving the whole sector in the exporting task, will also be of considerable importance.

Finally, it must be pointed out that this research has been carried out in an area that is relatively unexplored; hence the high degree of convergence and consistency of the responses obtained may in itself be considered as relevant as the actual forecasts outlined. However, the research carried out only forecasts broad future trends. The generic nature of these trends is, to a large extent, due to the complexity of the phenomena under consideration and the uncertainty of the environment in which they operate, in 
addition to the intrinsic features of the procedure followed. Moreover, this exercise only affords a "snapshot" of the issues explored. The research has to be continued on a regular basis over time in order to remain aware of key changes taking place in the sector and in its conditioning environment and to anticipate their effects.

\section{ACKNOWLEGMENTS}

The authors thank two anonymous referees for their valuable comments on an earlier version of this article.

\section{REFERENCES}

Alder, M., \& Ziglio, E. (1996) (Eds.). Gazing into the oracle: The Delphi method and its application to social policy and public health. London and Bristol, Pennsylvania: Jessica Kingsley.

Barrett, H.R., Ilbery, B.W., Browne, A.W., \& Binns, T. (1999). Globalization and the changing networks of food supply: The importation of fresh horticultural produce from Kenya into the UK. Transactions of the Institute of British Geographers, 24, pp. 159-174.

Bonazzi, M., \& Gomez Paloma, S. (1997). Euro-Mediterranean Policies between globalization and marginalization: The case of olive oil. In R.J. Loader, S.J. Henson, \& W.B. Traill (Eds.), Globalisation of the food industry: Policy and implications (pp. 177-197), Reading: Center for Food Economics Research, University of Reading.

Brock, J.L. (1981). A forecast for the grocery industry in the 1980's. Ann Arbor, MI: UMI Research Press.

Buckley, Ch. (1995). Delphi: A methodology for preferences more than predictions. Library Management, 16(7), pp. 16-19.

Calatrava Requena, J., \& Navarro Garcia, L. (1987). Defining agricultural research priorities by the Delphi method: Application to the Andalusian agricultural research programm. Paper presented at the "Ressource adjustment and European agriculture" 5th European Congress of Agricultural Economists, Balatonszeplak, Hungary (unpublished).

Coates, J.F. (1997). UK Delphi report merits study by R\&D leaders. Research-Technology Management, 1, pp. 5-7.

Connor, J.M. (1994). North America as a precursor of changes in Western European food-purchasing patterns. European Review of Agricultural Economics, 21(2), pp. 155-173.

Czinkota, M.R., \& Ronkainen, I.A. (1997). International business and trade in the next decade: Report from a Delphi study. Journal of International Business Studies, 28(4), pp. 827-844.

Czinkota, M.R., \& Ronkainen, I.A. (1992). Global marketing 2000: A marketing survival guide. Marketing Management, 1, pp. 36-45.

Dinar, A., Balakrishnan, T.K., \& Wambia, J. (1998). Political economy and political risks of institutional reform in the water sector. Policy Research Working Paper 1987, World Bank, Washington, DC. 
Fearne, A. (1989). The CAP in 1995 - a qualitative approach to policy forecasting. European Review of Agricultural Economics, 16(1), pp. 113-127.

Fonte, M. (1998). Food consumption models: Market times, tradition times. International Journal of Technology Management, 16(7), pp. 679-688.

Gunjal, K., \& Legault, B. ( 1995). Risk preferences of dairy and hog producers in Quebec. Canadian Journal of Agricultural Economics, 43(1), pp. 23-35.

Hooker, N.H., \& Caswell, J.A. (1996). Trends in food quality regulation: Implications for processed food trade and foreign direct investment. Agribusiness: An International Journal, 12(5), pp. 411-419.

International Olive Oil Council (1997). Projected olive oil production and consumption by 2005. CE/R.47/Doc. $n^{\circ} 3$, Madrid.

Johnson, J.L. (1976). A ten-year Delphi forecast in the electronic industry. Industrial Marketing Management, 5, pp. 45-55.

Josling, T., \& Tangermann, S. (1999). Implementation of the WTO Agreement on Agriculture and developments for the next round of negotiations. European Review of Agricultural Economics, 26(3), pp. 371-388.

Koskiala, S., \& Huhtanen, A. (1989). The Finnish Delphi study: Forecasting the extent of information technology use in libraries in 1996 and 2010. The Electronic Library, 7(3), pp. 170-175.

Landeta, J. (1999). El método Delphi: una técnica de previsión para la incertidumbre. Barcelona: Editorial Ariel.

Larréché, J.C., \& Montgomery, D.B. (1977). A framework for the comparison of marketing models: A Delphi study. Journal of Marketing Research, 14(4), pp. 487-498.

Lefebvre, L.A., Lefebvre, E., \& Préfontaine, L. (1996). Monitoring new technological developments in the electricity industry: An international perspective. Scientific Series, 96s-13, Montréal: Centre Interuniversitaire de Recherche en Analyse des Organisations.

Linstone, H.A., \& Turoff, M. (1975) (Eds.). The Delphi method: Techniques and applications. Reading and Massachusetts: Addison-Wesley.

Mahé, L.P. (1997). Environment and quality standards in the WTO: New protectionism in agricultural trade? A European perspective. European Review of Agricultural Economics, 24(3-4) , pp. 480-503.

Marginet Campos, J.L. (1999). Olive oil in Argentina: Production and processing. Olivae, 75, pp. 17-25.

Meulenberg, M.T.G., \& Steenkamp, J.E.B.M. (1991). Analysis of food consumption and food choice: A multidisciplinary approach. In H.E. Buchholz, \& H. Wendt (Eds.), Food Marketing and food industries in the single European market (pp. 283-294), Braunschweig: Institut für landwirtschaftliche Marktforschung der Bundesforschungsanstalt für landwirtschaft Braunschweig-Völkenrode.

Michell, V.W., \& McGoldrick, P.J. (1994). The role of geodemographics in segmenting and targeting consumer markets: A Delphi study. European Journal of Marketing, 28(5), pp. 54-72.

Mili, S. (1999). The olive oil sector: International challenges and future scenarios. Olivae, 75, pp. 8-16.

Organisation for Economic Cooperation and Development (1998). Agriculture policy reform. Policy Brief, 7.

Preble, J.F. (1983). Public sector use of the Delphi technique. Technological Forecasting and Social Change, 23, pp. $75-88$.

Rowe, G., \& Wright, G. (1999). The Delphi technique as a forecasting tool: Issues and analysis. International Journal of Forecasting, 15, pp. 353-375.

Rowe, G., \& Wright, G. (1996). The impact of task characteristics on the performance of structured group forecasting techniques. International Journal of Forecasting, 12, pp. 73-89.

Russo, D.M., \& McLaughlin, E.W. (1992). The year 2000: A food industry forecast. Agribusiness: An International Journal, 8(6), pp. 493-506.

Taverdet-Popiolek, N. (1998). La consommation d'engrais azotés en France: une prospective pour 2010. Cahiers d'Economie et de Sociologie Rurales, 46-47, pp. 30-69.

Tous Marti, J. (1995). The olive in Australia. Olivae, 55, pp. 10-15.

Turoff, M., \& Hiltz, S.R. (1996). Computer-based Delphi process. In: M. Alder, \& E. Ziglio (Eds.), Gazing into the oracle: The Delphi method and its application to social policy and public health (pp. 56-85), London and Bristol, Pennsylvania: Jessica Kingsley.

United States Department of Agriculture (1999). Oilseeds: World markets and trade. Foreign Agricultural Service, Circular Series, FOP 04-99, Washington, DC. 
Van Heerden, J.H. (1998). Economics science today: Obsolete in a changing world? The South African Journal of Economics, 66(3).

Watts, M. (1995). The agrarian question in the late twentieth century development. Paper presented at the "Spatial dimentions of development: Interaction between local, national and global" Conference, University of Copenhagen, 5-10 November (unpublished).

Woudenberg, F. (1991). An evaluation of Delphi. Technological Forecasting and Social Change, 40, pp. 131-150.

Ziglio, E. (1996). The Delphi method and its contribution to decision-making. In: M. Alder, \& E. Ziglio (Eds.), Gazing into the oracle: The Delphi method and its application to social policy and public health (pp. 3-33), London and Bristol, Pennsylvania: Jessica Kingsley.

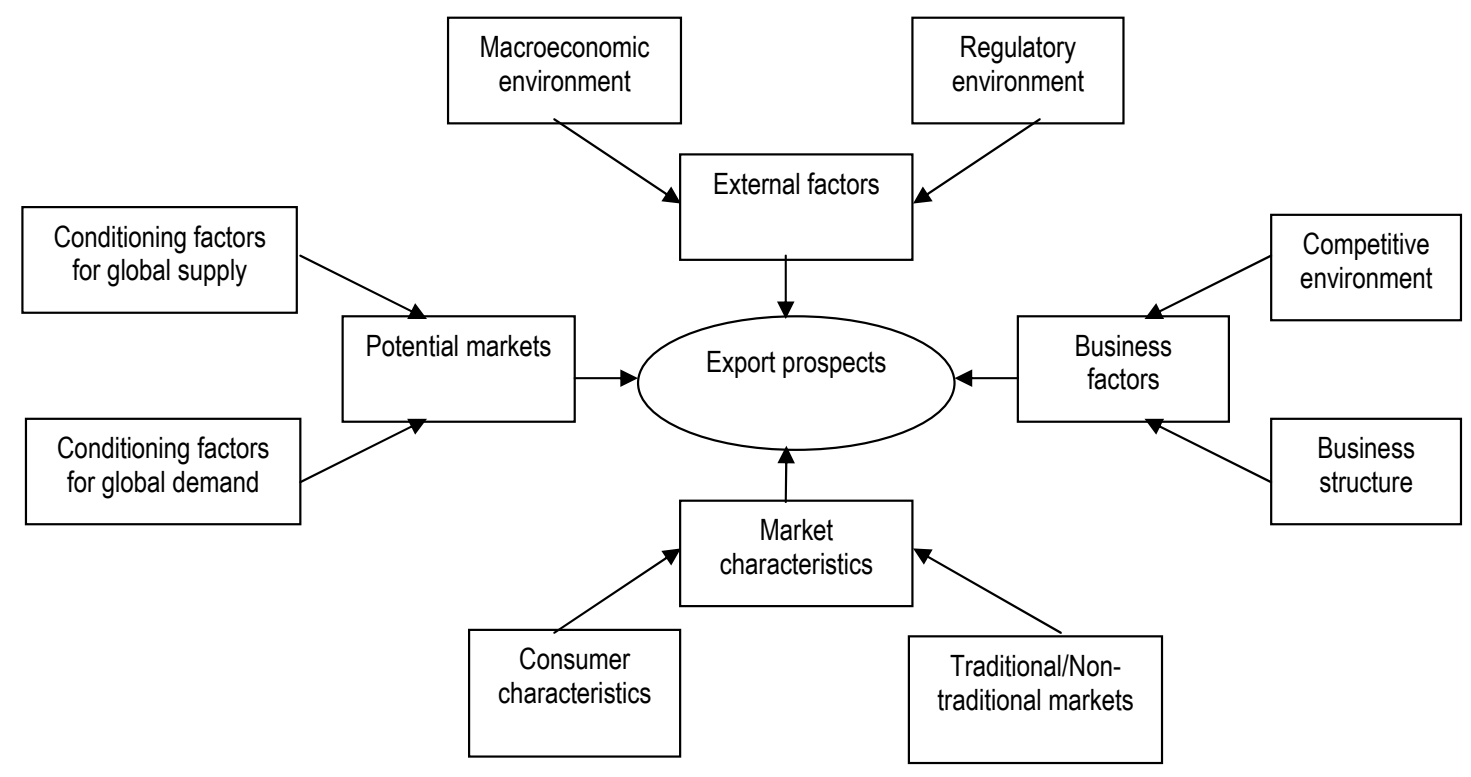

Figure 1. The conceptual model 
TABLE 1

Future increases in olive oil production: geographical location, magnitude and impact on Spanish exports

\begin{tabular}{|c|c|c|c|c|c|}
\hline & \multicolumn{2}{|c|}{ Magnitude of increase (1) } & \multicolumn{2}{|c|}{ Degree of impact (2) } & \multirow[t]{2}{*}{$\begin{array}{l}\text { Index for potential } \\
\text { impact (3) }\end{array}$} \\
\hline & $\bar{Z}$ & $\mathrm{CV}$ & $\bar{Z}$ & $\mathrm{CV}$ & \\
\hline Arronting & 298 & 3087 & $\mathrm{Nc}_{\mathrm{c}(5)}$ & $N c$ & $N c$ \\
\hline Australia & 2.76 & 30.80 & Ns & Ns & Ns \\
\hline Spain & 2.75 & 37.82 & 3.90 & 27.69 & 54 \\
\hline Tunisia & 2.55 & 27.84 & 3.28 & 25.30 & 45 \\
\hline Morocco & 2.53 & 32.41 & 2.97 & 36.03 & 43 \\
\hline Turkey & 2.46 & 31.71 & 3.08 & 30.84 & 41 \\
\hline Syria & 2.37 & 38.40 & 2.58 & 40.70 & 35 \\
\hline Portugal & 2.23 & 30.94 & 2.45 & 35.51 & 28 \\
\hline Greece & 1.98 & 29.29 & 2.88 & 31.94 & 29 \\
\hline Italy & 1.65 & $50.30(4)$ & 2.84 & 45.42 & 29 \\
\hline
\end{tabular}

(1) Expected annual average increase, quantified at 4 intervals (1 = Very moderate increase $=0-2 \% ; 2=$ Moderate increase = $2-5 \% ; 3=$ Sharp increase $=5-10 \% ; 4=$ Very sharp increase $=$ Over $10 \%$ )

(2) Scale from 1 to 5 (1 = Not significant; 2 = Very limited; 3 = Limited; 4 = Significant; 5 = Very significant).

(3) Index for potential impact $=[($ Magnitude of increase $\times$ Degree of impact $) / 20] \times 100$. Varies between 1 and 100.

(4) Although its CV is slightly above the set limit, this variable has been kept because of the size of Italian production.

(5) Not significant (CV $>50 \%$ and/or number of responses $<30)$. 
TABLE 2

Future increases in olive oil consumption: geographical location, magnitude and impact on Spanish exports

\begin{tabular}{|c|c|c|c|c|c|}
\hline & \multicolumn{2}{|c|}{ Magnitude of increase } & \multicolumn{2}{|c|}{ Degree of impact } & $\begin{array}{l}\text { Index for } \\
\text { potential } \\
\text { impact }\end{array}$ \\
\hline & $\bar{Z}$ & $\mathrm{CV}$ & $\bar{Z}$ & $\mathrm{CV}$ & \\
\hline Japan & 3.21 & 22.12 & 4.11 & 21.65 & 66 \\
\hline United States & 2.80 & 29.64 & 3.57 & 30.53 & 51 \\
\hline Australia & 2.66 & 27.82 & 3.59 & 32.59 & 49 \\
\hline Canada & 2.66 & 29.70 & 3.19 & 32.19 & 45 \\
\hline France & 2.55 & 31.76 & 3.47 & 31.12 & 45 \\
\hline Non-producer Community countries & 2.50 & 33.60 & 3.10 & 32.58 & 39 \\
\hline South-east Asia & 2.37 & 48.52 & 2.97 & 40.40 & 40 \\
\hline Argentina & 2.27 & 35.68 & 2.59 & 36.68 & 29 \\
\hline Brazil & 2.25 & 42.67 & 2.84 & 40.84 & 35 \\
\hline Producer Arab countries & 2.08 & 34.61 & 2.20 & 41.82 & 23 \\
\hline Mexico & 1.90 & 43.16 & 2.63 & 43.73 & 27 \\
\hline Non-producer Arab countries & 1.90 & 44.21 & 2.38 & 38.65 & 23 \\
\hline Turkey & 1.84 & 29.89 & 1.94 & 46.39 & 18 \\
\hline Other Latin American countries & 1.81 & 41.44 & 2.51 & 40.24 & 25 \\
\hline Central and Eastern Europe & 1.74 & 42.53 & 2.41 & 46.89 & 22 \\
\hline
\end{tabular}


TABLE 3

Main features of potential consumption and uses of olive oil. Relative agreement on the statements.

\begin{tabular}{|l|c|c|c|c|}
\hline & \multicolumn{2}{|c|}{ PCs } & \multicolumn{2}{|c|}{ NCPs } \\
\cline { 2 - 5 } & $\bar{Z}$ & CV & $\bar{Z}$ & CV \\
\hline $\begin{array}{l}\text { Growth in consumption will mostly be due to the demand of a segment of } \\
\text { population that is concerned about the quality of their diet rather than the relative } \\
\text { price level }\end{array}$ & 3.96 & 21.21 & 4.31 & 14.85 \\
$\begin{array}{l}\text { There is a large margin for growth in the groups of households which consume } \\
\text { two types of oil (olive and seed oils) if there is a change in the price ratio which is } \\
\text { currently unfavorable for olive oil }\end{array}$ & 3.46 & 31.21 & 3.26 & 30.06 \\
$\begin{array}{l}\text { There is a large margin for growth and greater diversification over the coming } \\
\text { years in both food uses for olive oil in preserves, dressings and other food } \\
\text { preparations, } \\
\text { and in non-food uses, particularly in the cosmetics and pharmaceuticals } \\
\text { industries }\end{array}$ & 3.68 & 26.63 & 3.26 & 33.74 \\
$\begin{array}{l}\text { There is a wide margin for growth in olive oil consumption amongst young, urban } \\
\text { populations, } \\
\text { and in consumption outside the home }\end{array}$ & 3.45 & 28.70 & 3.35 & 32.23 \\
\end{tabular}




\section{TABLE 4}

Attributes of olive oil for efficient marketing in potential markets. Relative importance of factors

\begin{tabular}{|l|c|c|c|c|}
\hline \multirow{2}{*}{} & \multicolumn{2}{|c|}{ PCs } & \multicolumn{2}{c|}{ NPCs } \\
\cline { 2 - 5 } & $\bar{Z}$ & CV & $\bar{Z}$ & CV \\
\hline & & & & \\
Fruity oils & 4.18 & 18.18 & 4.05 & 24.20 \\
Oils with low acidity & 4.15 & 16.39 & 4.25 & 16.23 \\
Oils with "personality" & 3.95 & 22.02 & 3.47 & 29.97 \\
Mild oils & 3.57 & 22.13 & 4.33 & 15.93 \\
& & & & \\
\hline
\end{tabular}

\section{TABLE 5}

Differentiation of Spanish oils in foreign markets. Relative importance of factors

\begin{tabular}{|l|r|r|}
\hline & $\bar{Z}$ & CV \\
\hline With respect to substitute products : & 4.75 & \\
Health and dietary recommendations & 4.65 & 10.32 \\
Natural product (in the virgin oil segment) & 4.39 & 15.72 \\
Presentation & 4.12 & 17.72 \\
Taste & 3.93 & 21.88 \\
Environment (in the ecological oil segment) & & \\
With respect to oils from competing countries: & 4.27 & \\
Brand & 3.98 & 17.80 \\
Country's image & 3.67 & 24.12 \\
Denomination of origin & 3.46 & 32.06 \\
Varieties of native and exclusive olives & \\
\hline
\end{tabular}

TABLE 6

Strengths and weaknesses of the Spanish olive oil export industry. Relative importance of factors

\begin{tabular}{|c|c|c|}
\hline & $\bar{Z}$ & CV \\
\hline Strengths : & & \\
Quality guarantee & 4.17 & 19.18 \\
Industrial capacity to suitably meet changes in demand & 3.83 & 24.54 \\
\hline
\end{tabular}




\begin{tabular}{|l|c|c|}
\hline Institutional commitment towards export promotion & 3.44 & 29.07 \\
Exporting tradition & 3.41 & 26.38 \\
High degree of business concentration & 3.34 & 23.35 \\
\multicolumn{1}{c|}{ Weaknesses : } & & \\
& & \\
Poor country image in many importer markets & 4.22 & 18.48 \\
Difficulty of setting up national trade channels & 4.21 & 20.66 \\
Insufficient brand promotion & 4.17 & 16.07 \\
Insufficient generic promotion & 4.07 & 18.92 \\
Large proportion of bulk products in exports & 3.99 & 25.31 \\
High prices in comparison with non-EU exports & 3.34 & 33.83 \\
Highly-regulated sector & 3.25 & 32.00 \\
\hline
\end{tabular}

TABLE 7

International marketing-mix. Relative importance of factors

\begin{tabular}{|c|c|c|}
\hline & $\bar{Z}$ & CV \\
\hline \multicolumn{3}{|l|}{ PRODUCT : } \\
\hline $\begin{array}{l}\text { Quality assurance } \\
\text { Oil type } \\
\text { Packaging } \\
\text { Labeling } \\
\text { Branding } \\
\text { After-sale warranty }\end{array}$ & $\begin{array}{l}4.64 \\
4.43 \\
4.20 \\
4.15 \\
4.05 \\
3.82\end{array}$ & $\begin{array}{l}11.64 \\
16.93 \\
16.90 \\
14.70 \\
21.97 \\
25.39\end{array}$ \\
\hline \multicolumn{3}{|l|}{ PRICE : } \\
\hline $\begin{array}{l}\text { Price discrimination within the range of olive oils } \\
\text { Price discrimination with respect to substitute oils } \\
\text { Price discrimination with respect to domestic market }\end{array}$ & $\begin{array}{l}3.87 \\
3.62 \\
3.23\end{array}$ & $\begin{array}{l}20.67 \\
22.93 \\
31.58\end{array}$ \\
\hline \multicolumn{3}{|l|}{ DISTRIBUTION : } \\
\hline $\begin{array}{l}\text { Regularity of supply } \\
\text { Permanence on the shelf } \\
\text { Delivery terms } \\
\text { Price stability } \\
\text { Terms of payment }\end{array}$ & $\begin{array}{l}4.61 \\
4.49 \\
4.30 \\
4.21 \\
3.59\end{array}$ & $\begin{array}{l}10.63 \\
11.14 \\
14.65 \\
16.39 \\
22.28\end{array}$ \\
\hline \multirow{2}{*}{\multicolumn{3}{|c|}{ COMMUNICATION : }} \\
\hline & & \\
\hline Information at points of sale & $\begin{array}{l}4.42 \\
3.98\end{array}$ & $\begin{array}{l}13.80 \\
16.58\end{array}$ \\
\hline
\end{tabular}




\begin{tabular}{|l|c|c|}
\hline Information in mass media & 3.95 & 18.23 \\
Presence at trade fairs and shows & & \\
\multicolumn{1}{|c|}{ Contents : } & & \\
& 4.66 & 11.80 \\
Information on dietary and nutritional benefits & 4.42 & 16.97 \\
Information on differences from other oils & 4.36 & 13.99 \\
Information on culinary uses & 4.31 & 18.10 \\
Information on the natural and environmental value of oil & 3.79 & 24.54 \\
Information on the geographic origin of the oil & & \\
& & \\
\hline
\end{tabular}

Samir Mili is a researcher in the Department of Economics at the Spanish Council for Scientific Research. He holds a Ph.D. in Agricultural Economics from the Polytechnic University of Madrid (1995), and a M.Sc. degree in Agricultural and Food Marketing from the International Centre for Advanced Mediterranean Agronomic Studies (1990). His current research interests include industrial organization of agricultural markets, international agricultural trade and policy, and food chain competence.

Manuel Rodríguez Zúñiga is a researcher in the Department of Economics at the Spanish Council for Scientific Research. He holds a Ph.D. in Agricultural Economics from the Polytechnic University of Madrid (1974). His current research interests include food and agribusiness marketing, international agricultural trade, innovation economics, and chain management in the food industry. 
